\title{
Proposal for updating the Aeronautic enlisted men's evaluating performance instrument based on the perceptions of senior and warrant officers
}

\author{
Guilherme dos Santos Araújo ${ }^{1}$, Fernando Oliveira de Araujo² \\ ${ }^{1}$ Brazilian Air Force - Officer Promotions Commission, Ministries Esplanade, Brasília, Brazil. \\ ${ }^{2}$ Fluminense Federal University, Production Engineering Department, Rio de Janeiro, Brazil.
}

How to cite: Araújo, G.S. and Araujo, F.O. (2020), “Proposal for updating the Aeronautic enlisted men's evaluating performance instrument based on the perceptions of senior and warrant officers", Brazilian Journal of Operations \& Production Management, Vol. 17, No. 3, e2020984. https://doi.org/10.14488/BJOPM.2020.035

\begin{abstract}
Goal: identify the key competencies, in the perception of the senior officers and the warrant officers of the Air Force, necessary for the enlisted men to perform their functions and subject to consideration for updating the existing performance evaluation instrument.

Design / Methodology / Approach: preliminarily, a documentary and bibliographic research was carried out, capable of supporting the construction of a questionnaire, which was answered by 674 senior officers and 727 warrant officers belonging to the research target audience. Data were analyzed using centrality and dispersion parameters, also considering Pearson's coefficient of variation.

Results: 29 competencies could be identified as being the main key competencies, highlighting those related to the alignment with military precepts.

Limitations: it is possible to obtain a large amount of data using questionnaire, but the method does not allow to deepen the structure and processes that involve the questions asked. Also, distortions can occur caused by the subjectivity present in the respondents' perception.

Practical implications: the results proved to be a proposal to updating the current performance evaluation system for enlisted men.

Value: the value of this research is its contribution to a better performance evaluation system for the Brazilian Air Force enlisted men.

Keywords: Competencies Survey; Performance Evaluation; Military Promotion; Professional Development.
\end{abstract}

\section{INTRODUCTION}

The militaries of the Brazilian Air Force are divided into officers and enlisted men. The latter make up the Corps of Enlisted Men, which has the staff of warrant officers and sergeants, stewards, corporals and soldiers, and the special staff of sergeants (Brasil, 2000). Using North Atlantic Treaty Organization Rank as reference, officers are classified from NATO CODE OF-1 to OF-10 and enlisted men from NATO CODE OR-1 to OR-9 (NATO, 2020).

Officers are prepared to exercise command, leadership and direction throughout their careers. Enlisted, on the other hand, will assist in the officers' activities, exercising technical level functions in the use of means and administration, among others (Brasil, 1980).

Financial support: None.

Conflict of interest: The authors have no conflict of interest to declare.

Corresponding author: guiarara06@gmail.com

Received: 29 May 2020

Accepted: 26 July 2020.

Editor: Fernando Oliveira de Araujo and Chrystyane Abreu. 
Regarding career advancement, the promotions of the Air Force military are based on meritocracy. For such promotions to take place fairly, a robust performance evaluation process is necessary.

According to the Aeronautic Personnel Management System, there are approximately 34 thousand enlisted (this total does not include active soldiers, who will not be addressed in this study) in the active exercise of their duties. These are several work areas such as aircraft mechanics, war material, guard and security, flight equipment, air traffic control.

There is also the figure of the temporary sergeant, who performs his duties in areas of interest to the Air Force for up to eight years. In this case, there are numerous technical areas, among them computers, electricity, electronics, radiology, among others (Brasil 2018).

In view of the wide variety of areas in which the enlisted work, as well as the different levels of complexity of their functions, the performance evaluation of these militaries is highlighted.

In 2016, an Air Force restructuring process began in order to improve the effectiveness of the employed resources (Brasil, 2016b). Until then, the Officers Promotions Commission, the organization responsible for evaluating officers' performance, and the Enlisted Men Promotions Commission, likewise responsible for evaluating enlisted' performance, worked independently, even physically separated. Due to the restructuring, the unification of the both Commissions' Secretaries, which now work in a unified way in Brasilia (Brasil, 2016a).

This situation brought up the need to analyze whether the competencies addressed in the performance evaluation instruments of the existing enlisted were adequate to the demands that these military personnel are submitted, in order to subsidize the proposal of an updated performance evaluation instrument, with key competencies required of enlisted.

Thus, this study aims to pursue answers to the following question research: What are the key competencies identified by senior officers (NATO CODE OF-3 to OF-5) and warrant officers (NATO CODE OR-9) of the Air Force, necessaries for enlisted perform their functions and that could account for the composition of a most robust and up-to-date performance evaluation tool for enlisted men?

The present study is structured in five sections, the second being a literature review that addresses the specific aspects of performance evaluation in Aeronautic, in addition to advancing the competency agendas. The third section presents the methodology used in the research. The fourth section, on the other hand, offers analysis and discussion of the results found. Finally, on the fifth and last, the final considerations and possible consequences of the research are presented.

\section{LITERATURE REVIEW}

For the reasons of this study, data was sought both in the Aeronautic documentation and in the science literature.

\section{Documentary research}

\section{Enlisted Men career precepts}

The military career has peculiarities that differentiate it from other careers. The institutional bases of the Armed Forces are hierarchy and discipline. And the notion of these two concepts permeates all levels of the Forces (Brasil, 1980).

The values of the military career are described in the Military Statute. It is interesting to highlight here the cult of historical traditions, the body spirit and technical and professional improvement (Brasil, 1980).

The military also complies with the strict observance of the principles of military ethics, including respect for the dignity of the person, obedience to current legislation, discretion in attitudes, the spirit of cooperation, among others (Brasil, 1980). 
The Military Statute also describes the duties of the military, such as dedication to the homeland, worship of national symbols, probity and loyalty, discipline and respect for hierarchy, compliance with obligations and orders, and the obligation to treat the subordinate with dignity (Brasil, 1980).

\section{Air Force performance evaluation}

Brazilian Air Force performance evaluation mixes with the own Force history. The Air Ministry was created in 1941 , January $20^{\text {th }}$, and in the same year, on November $20^{\text {th }}$, was created the Aeronautic Promotion Committee, responsible for identifying the merits of its officers. Since then, several methodologies were used for the sake of improving the evaluation of performance identification of the officers merits.

The officers performance evaluation is carried out in mixed form: they are evaluated for presented competency doing their duties and also by goals evaluation (Brasil, 2015).

Enlisted Men Promotions Commission was established in 1941, December $16^{\text {th }}$ and acts in the process of performance evaluation and identification of merits. They are evaluated only in terms of the competencies today described as necessary for the performance of their functions (Brasil, 2013).

In both cases, the competencies that will be the basis of the performance evaluation are described through observable behaviors.

There are significant differences in the performance evaluation processes between officers and enlisted. With regard to officers, there are 34 behaviors grouped into 6 factors, as shown in Chart 1 - Behaviors of performance evaluation of career officers:

Chart 1 - Behaviors of the performance evaluation of career officers.

\begin{tabular}{|c|c|c|}
\hline LEADERSHIP FACTOR & KNOWLEDGE FACTOR & MILITARY FACTOR \\
\hline Sets an example & Seeks self-development & Accepts decisions \\
\hline $\begin{array}{l}\text { Fair and consistent with } \\
\text { subordinates }\end{array}$ & Holds and applies knowledge & Advises with property \\
\hline Sets goals for subordinates & Has general culture compatible & Follows principles and values \\
\hline Stimulates teamwork & & Meets standards \\
\hline Manages competencies & & It's punctual \\
\hline Encourages development & & Maintains personal presentation \\
\hline Mobilizes subordinates & & \\
\hline Provides feedback & & \\
\hline Care for well-being & & \\
\hline ORGANIZATIONAL FACTOR & INTERPERSONAL FACTOR & COMMUNICATION FACTOR \\
\hline Manages resources & Maintains self-control & Written communication \\
\hline Meet deadlines & Cooperates in team work & Oral communication \\
\hline Decides properly & Is receptive to criticism & Listen carefully \\
\hline Adapts to changes & Relates to harmony & \\
\hline Identifies and solves problems & Honest opinions & \\
\hline \multicolumn{3}{|l|}{$\begin{array}{l}\text { Judges with discretion and } \\
\text { exemption }\end{array}$} \\
\hline \multicolumn{3}{|l|}{ Persists when conducting tasks } \\
\hline Plans and organizes actions & & \\
\hline
\end{tabular}

Source: adapted from Officers Promotions System - SISPROM (2018).

Chart 1 systematizes existing behaviors in SISPROM, considered in the annual performance evaluation of career officers. The factors are composed of competencies that allow the officer to be evaluated in his technical-administrative environment, as well as in terms of military aspects. 
For the temporary officers, those who can remain in the Force for up to 8 years, their evaluation has 25 behaviors as shown in Chart 2.

Chart 2 - Temporary officers' performance evaluation behaviors.

\begin{tabular}{|ccc|}
\hline \multicolumn{2}{|c|}{ CONCEPTS } \\
\hline $\begin{array}{c}\text { Adheres to decisions and } \\
\text { standards }\end{array}$ & Advises with property & Seeks self-development \\
\hline Follows principles and values & Maintains self-control & Meets deadlines \\
\hline Decides properly & Holds and applies knowledge & Adapts to changes \\
\hline It's punctual & Written communication & Oral communication \\
\hline Identifies and solves problems & Judges with discretion and & exemption \\
Listens and tries to understand & Cooperates in works & Paintains personal presentation \\
\hline Treats with respect & Is receptive to criticism & Relates to harmony \\
\hline Mobilizes subordinates & Sets an example & Fair and consistent with \\
Provides feedback & &
\end{tabular}

Chart 2 shows the existent behaviors regarding temporary officers. Just as happens with the career officers, evaluators record their observations annually. This is a list that provides a simplified evaluation of these officers, as they will not continue their career to the highest positions.

The evaluation of the officers, both career and temporary, also includes the registration, at the beginning of the process, of the evaluated officer tasks, which will be the target of evaluation throughout the process regarding the achievement of the goals established (Brasil, 2015).

The evaluation of enlisted is done by observing 15 behaviors, as consolidated in Chart 3 . There is no difference in behaviors for temporary ones.

Chart 3 - Enlisted men's performance evaluation behaviors.

\begin{tabular}{|ccc|}
\hline & BEHAVIORAL FACTORS & \\
\hline Quality of work & Productivity at work & Professional knowledge \\
\hline Planning & Judgment & Responsibility \\
\hline Leadership & Initiative & Adaptability \\
\hline Efficiency in teamwork & Use of material resources & Oral and written communication \\
\hline Discipline & Personal presentation & Relationship in workplace \\
\hline
\end{tabular}

Source: adapted from Brasil (2013).

Chart 3 shows the existing behavior in the Enlisted Men Evaluation System to conduct their annual performance evaluation. The performance evaluation of officers and enlisted takes place in different systems. The difference, in terms of the competencies observed for enlisted in relation to the officers, is due to the fact that such evaluative processes have been managed until then by different organizations.

\section{Professional competencies}

The use of competencies described by observable behaviors already occurs for both officers and enlisted performance evaluation.

The concept of competencies has several definitions, which can be grouped into two major groups: the first, composed mainly by Americans authors as Boyatzis (1982) and 
Spencer and Spencer (1993), which considers the competencies as a set of knowledge and qualifications that would provide a better performance in the execution of the assigned tasks.

Another group of authors, like Lebortef (1995) and Zarifian (1996), contests the concept of competency as a stock and seeks to associate competencies with achievements. For this second group, there are no competencies if the worker does not use his repertoire in the daily practice at work. The competency will only exist in cases where it is put into action (Dutra, 2011).

For a third group of authors, the definition of competency is the sum of the two lines of the above groups. Competence, in this case, can be considered as the previous qualifications that the person has and also as the ability that the person has to fulfill their tasks, to deliver what is under their responsibility (Dutra, 2014).

For Zarifian (2001, p. 66), "professional competency is a combination of knowledge, know-how, experience and behavior that is exercised in a precise context. It is contested when used in a professional situation, from which it is subject to validation".

It is not enough for the professional to have knowledge, skills or attitude, if they are not put into practice for the fulfillment of tasks at work.

The concept of power may be represented by the symbol "C.H.A." (knowledge, skills and attitude). Knowledge is knowing. It is the accumulated knowledge throughout the person's life and career. The ability, on the other hand, is knowing how to use knowledge in order to accomplish the expected deliverables. Finally, the attitude is the intention to do what you do, to try to perform the tasks in the best way. It involves social and affective aspects (Carbone et al., 2016).

Mussak (2010) started to use the acronym "C.H.A.V.E.", adding the dimensions Values and Surroundings. For this author, it is not possible to talk about having competencies and delivering results in the current context if there are no values added to that competence. Likewise, he highlights the importance of the environment where the competency will be applied (surroundings), where are the conditions for applying it.

This last understanding of competency has a lot of adherence to militarism, since the military has clear values inscribed in the Military Statute. And the observance of values does not dissociate at any time from the discharge of their duties.

If there are individual competencies, it should be noted the existence also of organizational competencies. Such competencies are associated with the company's resources, such as its infrastructure, its brand, its image, its administrative systems, its organizational culture (Fleury and Fleury, 2008).

The organizational culture is constantly changing, adjusting over time (Ludolf et al., 2017). This culture is highly valued in the military, since various rites, rituals and ceremonies are part of the military everyday throughout his career. It can be considered as organizational competencies.

The organizational culture is the way the organization behaves, through its employees. It is how the group learns from the problems and adapts from the solutions found, which are validated and transmitted to the new members (Arbache and Dutra, 2018).

\section{Performance evaluation and competencies identification}

The performance evaluation is, in essence, an instrument to promote the delivery of best results, continuous improvement, either through the feedback or the lack of training identification, among others. It is "a tool to support management, and an element of mobilizing employees to generate results and fulfill the organizational mission" (Carbone et al., 2016, p. 104).

The performance evaluation carried out today for the Air Force military uses the method of graphic scales, in which "[...] the evaluation factors are behaviors and attitudes selected and valued by the organization. [...] Each factor is defined as a summary description, simple and objective [...]" (Chiavenato, 2014, p. 217). 
For the officers, there is also a performance evaluation by goals, in which the evaluators will define, together with the evaluated ones, the goals that should be reached during the evaluation period. Chiavenato (2014) calls this type of evaluation Participative Evaluation by Objective (APPO) and highlights the importance of the formulation of objectives being consensual and of the commitment of the appraised regarding the achievement of the established goals.

The presented behaviors really represent the desired competencies, because according to Cripe and Mansfield (2003, p. 14), these competencies "include observable behaviors. They also include behaviors, thought processes, competencies and traits that are not directly observable".

To carry out a mapping of competencies, the first step is exactly to identify which individual and organizational competencies are necessary for the organization to achieve its objectives (Carbone et al., 2016). Cripe and Mansfield (2003) highlight that the identification of the necessary competencies is the first step also for the development of such competencies in the organization.

In addition to Cripe and Mansfield (2003), other authors have some desirable competencies for the professional. Fleury and Fleury (2008), for example, proposes as professional ones: knowing how to act and mobilize, able to communicate and learn, learn to compromise and take responsibilities, and have strategic vision.

Cripe and Mansfield (2003) subdivides essential competencies in three groups: dealing with people, with business and self-management ones. In the first group, divided them in dealing with others and communicate and influence. In the second group, they are subdivided in to prevent and solve problems and achieve results. Among the presented competencies, the following stand out: offering support, encouraging teamwork, attention to communication, oral and written communication, interpersonal awareness, anticipation, initiative, results orientation, self-confidence, stress management and flexibility.

\section{RESEARCH METHODOLOGY}

To check which competencies are needed to enlisted perform various duties proved to be feasible by the systematization of a competencies list understood as suitable for enlisted, which was submitted to the audience research through questionnaire.

\section{CHARACTERIZATION OF THE RESEARCH SUBJECTS}

To carry out the research were used officers and enlisted with length of service and appropriated experience to achieve the research goals. In this way, the participating population was limited to senior officers and warrant officers.

Senior officers were selected because they have experience in performing duties as officers, including evaluating the enlisted performance under their subordination. It is noteworthy that the cycle of senior officers is composed of majors, lieutenant-colonels and colonels.

These military evaluate the performance of both officers and enlisted and can be in the reviewer function in both cases, depending on their experience.

Thus, questionnaires were sent to a total of 3,140 senior officers. This number corresponds to all officers on active duty, covering officers in the three ranks, of the different specialties, distributed in Brazil's organizations and abroad, and also those hired for the Provision of Task for the Right Time (PTTC) and those Designated for the Active Service (DSA)

The PTTC is a military in reserve (retired) hired for a certain time to carry out military activities due to their extensive professional experience and recognized technical and administrative competence (Brasil, 2017). Those in DAS condition are militaries in reserve assigned to active service again on a transitory basis (Brasil, 1983).

Warrant officers are the enlisted with higher rank, with the most experience and length of service. They are militaries who have already gone through different functions, often in 
more than one location and/or the military organization, which provides a broader view of the competencies needed to perform their duties. Questionnaires were sent to 4,643 warrant officers, this amount corresponding to all on active duty in the various existing specialties, distributed in Brazil's organizations and abroad, as well as those in the PTTC and DSA situation.

For the calculation of both samples, it was used the sample equation constant in Equation 1 (Almeida, 2013).

$\boldsymbol{n} \geq \frac{\boldsymbol{N} \hat{\boldsymbol{p}} \hat{\boldsymbol{q}} \boldsymbol{z}_{(1-\alpha / 2)}^{2}}{(N-1) \boldsymbol{e}^{2}+\hat{\boldsymbol{p}} \hat{\boldsymbol{q}} \boldsymbol{z}_{(1-\alpha / 2)}^{2}}$

Where:

$\mathbf{n}=$ sample size

$\mathbf{N}=$ population size

$\boldsymbol{p}^{\wedge}=$ proportion estimation

$q^{\wedge}=1-p$

$\mathbf{z}^{2}{ }_{(1-\alpha / 2)}=$ trust level

$\mathbf{e}=$ error estimation

As already mentioned, questionnaires were sent to a universe of 3,140 senior officers and 4,643 warrant officers. Of this total, 674 senior officers and 727 warrant officers responded to the questionnaire. For the total number of emails sent, the sample of respondents guarantees a $95 \%$ confidence level, with a sampling error of $4 \%$ for this survey.

\section{Data collection techniques}

A documentary review was carried out on the performance evaluation in Aeronautic, as well as on documents related to the theme and that had a direct relationship with the enlisted. There was also a bibliography review on the subject, in order to outline aspects about the same competencies and performance evaluation.

Then, questionnaires were sent to both groups, in order to raise the necessary competencies for the enlisted to exercise their functions.

\section{Data collection instrument}

The research instrument used was a mixed questionnaire, composed of open and closed questions. The choice of this type of instrument took into account the possibility of the participation of a larger number of military personnel, as well as obtaining information in a shorter time span (Vergara, 2012).

In the closed questions, a Likert- type classification scale was used (Vergara, 2012), composed of five alternatives: not at all relevant; little relevant, moderately relevant, truly relevant; and totally relevant.

The questionnaire had explanations about the work for the participants, questions of general identification of the respondents and guidance for completing it.

In order to identify the competencies that would compose the questionnaire, the existing competencies presented in the evaluation instruments of officers and enlisted were used. In order to complement these competencies, others were sought in the literature, which, after being confronted with the existing ones and with the analyzed documentation, were considered in the research instrument.

A pre-test was carried out with six psychologists, including officers and civilians, who work in the area of performance evaluation of officers and enlisted, in order to validate the instrument and verify aspects such as clarity and precision, the number of questions and these competencies and order (Gil, 2010). Their perceptions were used to improve the instrument. 
The questionnaire was prepared using the Google Forms tool, which made it possible to guarantee the confidentiality of the participants and the tabulation of the data obtained. The use of this tool facilitated the sending to participants through functional e-mail.

\section{Data analysis procedures}

After tabulating, the obtained data was performed to calculate the competency average $(\bar{X})$, using the values assigned to the answers from 1 to 5 and based in their relative frequencies, as Equation 2 (Mariano and Meneses, 2014).

$$
\bar{X}=\frac{\sum f \cdot X}{\mathrm{n}}
$$

Where:

$\Sigma f . X=$ sum of the frequencies $f i$ multiplied by the value $X$

$\mathbf{n}=$ sample size

Data was analyzed using software $R$, version 3.6.2. Boxplots graphics were used to present the distribution of responses per group in order to facilitate the visualization of these and the minimum and maximum in each group. (Marôco, 2014).

It was also calculated the coefficient of variation of Pearson for supporting the analysis of relative dispersion occurred in each competence, according to the calculated standard deviation as Formula in Equation 3 (Martins, 2005).

$$
C V=\frac{S}{\bar{X}} \cdot 100
$$

Where:

$\mathrm{S}=$ standard deviation

$\bar{X}=$ sample average

According to Martins (2005), values of the Coefficient of Variation below $15 \%$ correspond to a low dispersion; greater than or equal to $15 \%$ and less than $30 \%$ at medium dispersion; and values greater than or equal to $30 \%$ correspond to a high dispersion. As the smaller the dispersion the more homogeneous the results are, the CV range below $15 \%$ was used in this research, equivalent to a low dispersion, to identify the competencies that were considered in the final result.

\section{Limitations of the method used and obtained results}

As for the existing limitations, the possibility of differences in perception among respondents to the questionnaire regarding the competencies necessary for enlisted to perform their functions is highlighted. According to Gil (2010), distortions can occur caused by the subjectivity present in the respondents' perception.

One should also consider the little depth obtained when using the lifting technique. It was possible to obtain a large amount of data, but the method does not allow to deepen the structure and processes that involve the questions asked (Gil, 2010).

\section{ANALYSIS AND RESULTS DISCUSSION}

This section presents the data collected through the questionnaire. As mentioned, were received 674 responses from senior officers and 727 of warrant officers, wherein the sample of respondents granting a confidence level of $95 \%$, with an error sample of $4 \%$ for this study.

The distribution of senior officers participants is shown in Figure 1: 
What is your specialty?

674 answers

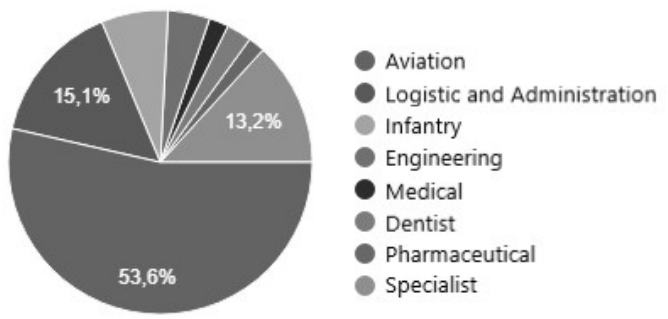

Figure 1 - Distribution of senior officers by specialty. Source: Google Forms.

Most respondents were Aviation Officers (53.6\%), followed by the Logistic and Administration Officers (with 15.1\%) and the Engineers Officers (13.2\%). As for the responding rank, the distribution is shown in Figure 2:

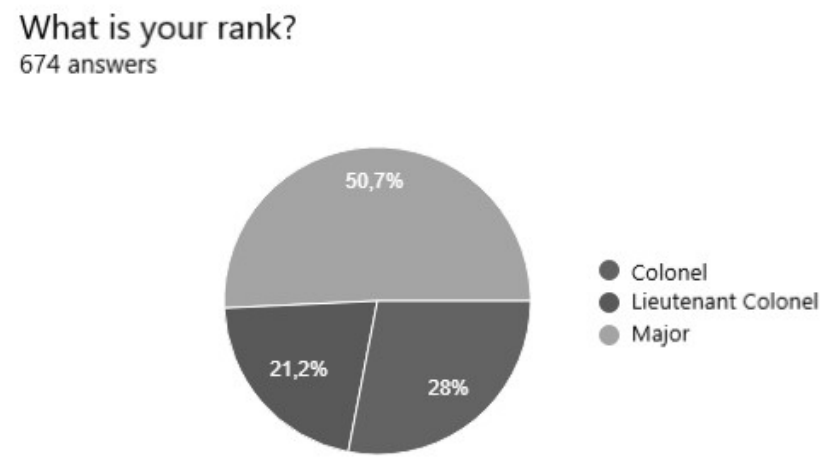

Figure 2 - Rank of senior officers. Source: Google Forms.

More than half of the answers obtained came from the majors (50.7\%). Regarding the service time of the respondent officers, the distribution was as shown in Figure 3:

Service time:

674 answers

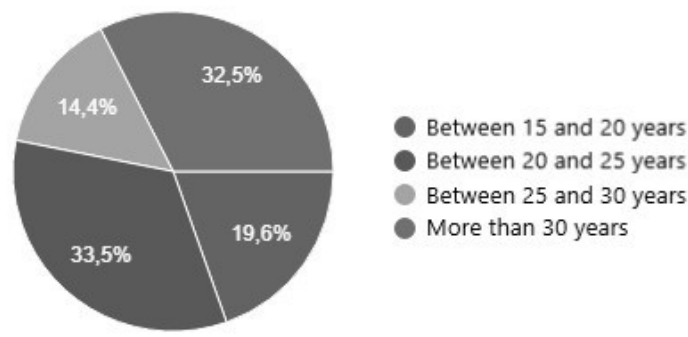

Figure 3 - Senior officers' service time. Source: Google Forms. 
The majority of respondents had between 20 and 25 years (33.5\%) or more than 30 years of service (32.5\%), what corroborates the expected experience of research participants.

As for the warrant officers, the profile of the research participants was as shown in Figure 4:

What is your specialty? 727 answers

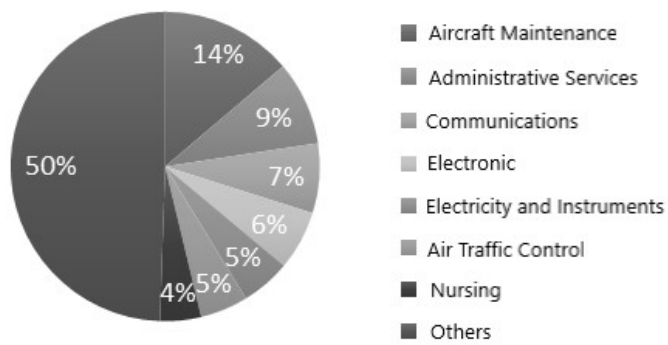

Figure 4 - Warrant officers' specialties. Source: Google Forms.

Most warrant officers respondents were from Aircraft Maintenance specialty (14\%), followed by Administrative Services (9\%) and Communications (7\%). The 50\% indicated correspond to other specialties of the respondents, among them Intelligence, Technical Supply, Construction, Infrastructure and Metallurgy, Guard and Security, Music, Armament and Meteorology. As for the service time of the respondents, the distribution is shown in Figure 5:

Service time:

727 answers

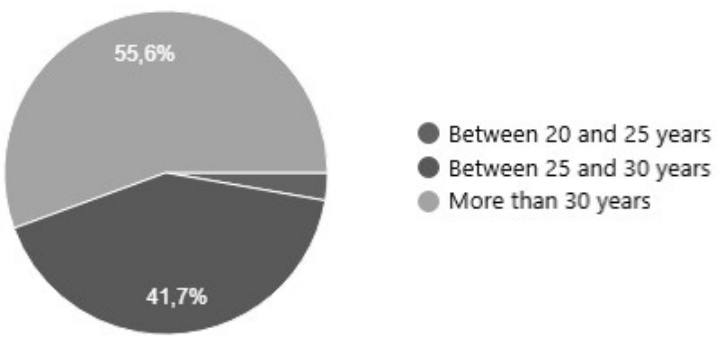

Figure 5 - Warrant officers' service time. Source: Google Forms.

Most of the warrant officers participating in the survey had more than 30 years of service (55.6\%), which corroborates, as with the officers, the experience expected from the survey participants.

For senior officers, the responses regarding the survey of competencies necessary for the performance of enlisted in their functions were distributed according to Chart 4. In order to facilitate the presentation of data analysis, competencies were classified from C1 to C37. 
Chart 4 - Distribution of senior officers' responses.

\begin{tabular}{|c|c|c|c|c|c|}
\hline COMPETENCIES & \multicolumn{5}{|c|}{ Number of responses } \\
\hline ALIGNMENT WITH MILITARY PRECEPTS: & 1 & 2 & 3 & 4 & 5 \\
\hline C1. Accept superior decisions. & $0.15 \%$ & $0.15 \%$ & $0.74 \%$ & $14.26 \%$ & $84.71 \%$ \\
\hline C2. Advising with loyalty and honesty of purpose. & $0.15 \%$ & $0.15 \%$ & $0.74 \%$ & $4.41 \%$ & $94.56 \%$ \\
\hline $\begin{array}{c}\text { C3. Behave in accordance with military principles and } \\
\text { values and with organizational culture (rites, rituals, } \\
\text { ceremonies and social events). }\end{array}$ & $0.15 \%$ & $0.59 \%$ & $3.82 \%$ & $21.18 \%$ & $74.26 \%$ \\
\hline $\begin{array}{l}\text { C4. Comply with and demand compliance with the } \\
\text { Institution's rules. }\end{array}$ & $0.15 \%$ & $0.44 \%$ & $1.03 \%$ & $11.91 \%$ & $86.47 \%$ \\
\hline C5. Be punctual. & $0.15 \%$ & $0.15 \%$ & $3.82 \%$ & $29.41 \%$ & $66.47 \%$ \\
\hline $\begin{array}{l}\text { C6. Maintain the personal presentation and their } \\
\text { uniforms in accordance with the standards established } \\
\text { by the Institution. }\end{array}$ & $0.15 \%$ & $0.74 \%$ & $7.79 \%$ & $37.35 \%$ & $53.97 \%$ \\
\hline \multirow{2}{*}{ ORGANIZATIONAL: } & \multicolumn{5}{|c|}{ Number of responses } \\
\hline & 1 & 2 & 3 & 4 & 5 \\
\hline $\begin{array}{l}\text { C7. Adopt techniques and methods of using resources } \\
\text { that optimize the meeting of organizational needs. }\end{array}$ & $0.29 \%$ & $0.15 \%$ & $4.56 \%$ & $39.26 \%$ & $55.74 \%$ \\
\hline $\begin{array}{l}\text { C8. Be flexible when facing new ideas and situations, } \\
\text { adapting to changes. }\end{array}$ & $0.29 \%$ & $0.29 \%$ & $5.15 \%$ & $38.68 \%$ & $55.59 \%$ \\
\hline $\begin{array}{l}\text { C9. Identify potential problems and take timely action, } \\
\text { regardless of prior orders and guidelines. }\end{array}$ & $0.29 \%$ & $2.06 \%$ & $9.12 \%$ & $40.59 \%$ & $47.94 \%$ \\
\hline $\begin{array}{l}\text { C10. Establish procedures to ensure control and quality } \\
\text { in the delivery of the task. }\end{array}$ & $0.15 \%$ & $1.47 \%$ & $5.29 \%$ & $36.18 \%$ & $56.91 \%$ \\
\hline $\begin{array}{l}\text { C11. Demonstrate support for innovation and } \\
\text { organizational changes necessary to improve the } \\
\text { organization's effectiveness. }\end{array}$ & $0.29 \%$ & $0.88 \%$ & $9.71 \%$ & $38.68 \%$ & $50.44 \%$ \\
\hline \multirow{2}{*}{ KNOWLEDGE: } & \multicolumn{5}{|c|}{ Number of responses } \\
\hline & 1 & 2 & 3 & 4 & 5 \\
\hline $\begin{array}{l}\text { C12. Search for knowledge that will improve the } \\
\text { performance of your role (self-development). }\end{array}$ & $0.29 \%$ & $0.59 \%$ & $7.35 \%$ & $34.85 \%$ & $56.91 \%$ \\
\hline $\begin{array}{l}\text { C13. Retain and apply the technical-professional } \\
\text { knowledge required for your function. }\end{array}$ & $0.15 \%$ & $0.29 \%$ & $1.32 \%$ & $20.59 \%$ & $77.65 \%$ \\
\hline $\begin{array}{l}\text { C14. Have a general culture compatible with the stage } \\
\text { of your career. }\end{array}$ & $0.74 \%$ & $1.32 \%$ & $17.21 \%$ & $45.59 \%$ & $35.15 \%$ \\
\hline \multirow{2}{*}{ INTERPERSONAL: } & \multicolumn{5}{|c|}{ Number of responses } \\
\hline & 1 & 2 & 3 & 4 & 5 \\
\hline $\begin{array}{l}\text { C15. Maintain self-control in situations of pressure and } \\
\text { stress. }\end{array}$ & $0.15 \%$ & $0.88 \%$ & $3.53 \%$ & $30.88 \%$ & $64.56 \%$ \\
\hline $\begin{array}{l}\text { C16. Cooperate in teamwork in order to optimize the } \\
\text { achievement of the proposed objectives. }\end{array}$ & $0.29 \%$ & $0.00 \%$ & $2.06 \%$ & $29.12 \%$ & $68.53 \%$ \\
\hline C17. Receive mature criticism. & $0.29 \%$ & $1.18 \%$ & $5.44 \%$ & $36.18 \%$ & $56.91 \%$ \\
\hline $\begin{array}{l}\text { C18. To relate harmoniously in the work environment } \\
\text { and in social and institutional events. }\end{array}$ & $0.59 \%$ & $1.18 \%$ & $11.18 \%$ & $38.53 \%$ & $48.53 \%$ \\
\hline C19. State your opinions frankly and appropriately. & $0.15 \%$ & $0.44 \%$ & $5.88 \%$ & $32.06 \%$ & $61.47 \%$ \\
\hline $\begin{array}{l}\text { C20. Treat your superiors, peers and subordinates with } \\
\text { respect and education. }\end{array}$ & $0.15 \%$ & $0.15 \%$ & $1.32 \%$ & $12.94 \%$ & $85.44 \%$ \\
\hline
\end{tabular}




\begin{tabular}{|c|c|c|c|c|c|}
\hline \multirow{2}{*}{ COMUNNICATION: } & \multicolumn{5}{|c|}{ Number of responses } \\
\hline & 1 & 2 & 3 & 4 & 5 \\
\hline $\begin{array}{l}\text { C21. Develop clear, objective and grammatically correct } \\
\text { texts. }\end{array}$ & $0.29 \%$ & $1.18 \%$ & $11.47 \%$ & $47.79 \%$ & $39.26 \%$ \\
\hline $\begin{array}{l}\text { C22. Express yourself orally in a clear, logical and } \\
\text { concise manner. }\end{array}$ & $0.15 \%$ & $1.03 \%$ & $8.09 \%$ & $50.00 \%$ & $40.74 \%$ \\
\hline $\begin{array}{l}\text { C23. Listen carefully and react constructively to the } \\
\text { other's point of view. }\end{array}$ & $0.29 \%$ & $0.74 \%$ & $7.65 \%$ & $42.35 \%$ & $48.97 \%$ \\
\hline \multirow[b]{2}{*}{ DELIVERY (TASK RESULTS): } & \multicolumn{5}{|c|}{ Number of responses } \\
\hline & 1 & 2 & 3 & 4 & 5 \\
\hline C24. Comply with the established deadlines. & $0.15 \%$ & $0.29 \%$ & $1.47 \%$ & $15.59 \%$ & $82.50 \%$ \\
\hline $\begin{array}{l}\text { C25. Maintain commitment to goals in the face of } \\
\text { obstacles and frustrations. }\end{array}$ & $0.15 \%$ & $0.59 \%$ & $1.32 \%$ & $31.62 \%$ & $66.32 \%$ \\
\hline $\begin{array}{l}\text { C26. Plan, organize and prioritize actions to achieve the } \\
\text { objectives. }\end{array}$ & $0.15 \%$ & $0.88 \%$ & $5.88 \%$ & $38.24 \%$ & $54.85 \%$ \\
\hline $\begin{array}{l}\text { C27. Judge with discretion and impartiality the aspects } \\
\text { involved in carrying out the task. }\end{array}$ & $0.15 \%$ & $1.18 \%$ & $8.38 \%$ & $42.79 \%$ & $47.50 \%$ \\
\hline $\begin{array}{l}\text { C28. Establish challenging goals with your boss, but } \\
\text { achievable, in the fulfillment of tasks. }\end{array}$ & $1.18 \%$ & $1.91 \%$ & $19.85 \%$ & $47.94 \%$ & $29.12 \%$ \\
\hline $\begin{array}{l}\text { C29. Keep your boss informed about progress and } \\
\text { problems in carrying out tasks, avoiding surprises. }\end{array}$ & $0.15 \%$ & $0.59 \%$ & $1.91 \%$ & $21.62 \%$ & $75.74 \%$ \\
\hline \multirow[t]{3}{*}{$\begin{array}{l}\text { C30. Take responsibility for your own mistakes, not } \\
\text { blaming other team members. }\end{array}$} & $0.29 \%$ & $0.29 \%$ & $2.06 \%$ & $13.82 \%$ & $83.53 \%$ \\
\hline & \multicolumn{5}{|c|}{ Number of responses } \\
\hline & 1 & 2 & 3 & 4 & 5 \\
\hline $\begin{array}{l}\text { C31. Set an example of behavior and conduct for your } \\
\text { peers and subordinates. }\end{array}$ & $0.15 \%$ & $0.29 \%$ & $2.94 \%$ & $17.65 \%$ & $78.97 \%$ \\
\hline C32. Stimulate body spirit and teamwork. & $0.15 \%$ & $0.44 \%$ & $3.82 \%$ & $30.44 \%$ & $65.15 \%$ \\
\hline $\begin{array}{l}\text { C33. Encourage the personal and professional } \\
\text { development of your team members. }\end{array}$ & $0.29 \%$ & $1.32 \%$ & $10.29 \%$ & $40.00 \%$ & $48.09 \%$ \\
\hline $\begin{array}{l}\text { C34. Mobilize and guide team members with a view to } \\
\text { achieving the established goals. }\end{array}$ & $0.15 \%$ & $1.03 \%$ & $6.91 \%$ & $36.03 \%$ & $55.88 \%$ \\
\hline $\begin{array}{l}\text { C35. Provide feedback to subordinates regarding the } \\
\text { results obtained. }\end{array}$ & $0.59 \%$ & $0.88 \%$ & $7.35 \%$ & $33.24 \%$ & $57.94 \%$ \\
\hline $\begin{array}{l}\text { C36. Ensure the well-being of your peers in the } \\
\text { workplace. }\end{array}$ & $0.29 \%$ & $0.44 \%$ & $7.65 \%$ & $32.65 \%$ & $58.97 \%$ \\
\hline C37. Increase the commitment of others to work. & $0.88 \%$ & $0.88 \%$ & $10.59 \%$ & $40.59 \%$ & $47.06 \%$ \\
\hline
\end{tabular}

Source: the author.

Using a boxplot graph, it was possible to identify the range of distribution of the responses of senior officers. The responses are represented by groups in Figure 6: 


\section{Boxplot - Senior Officers' Responses}

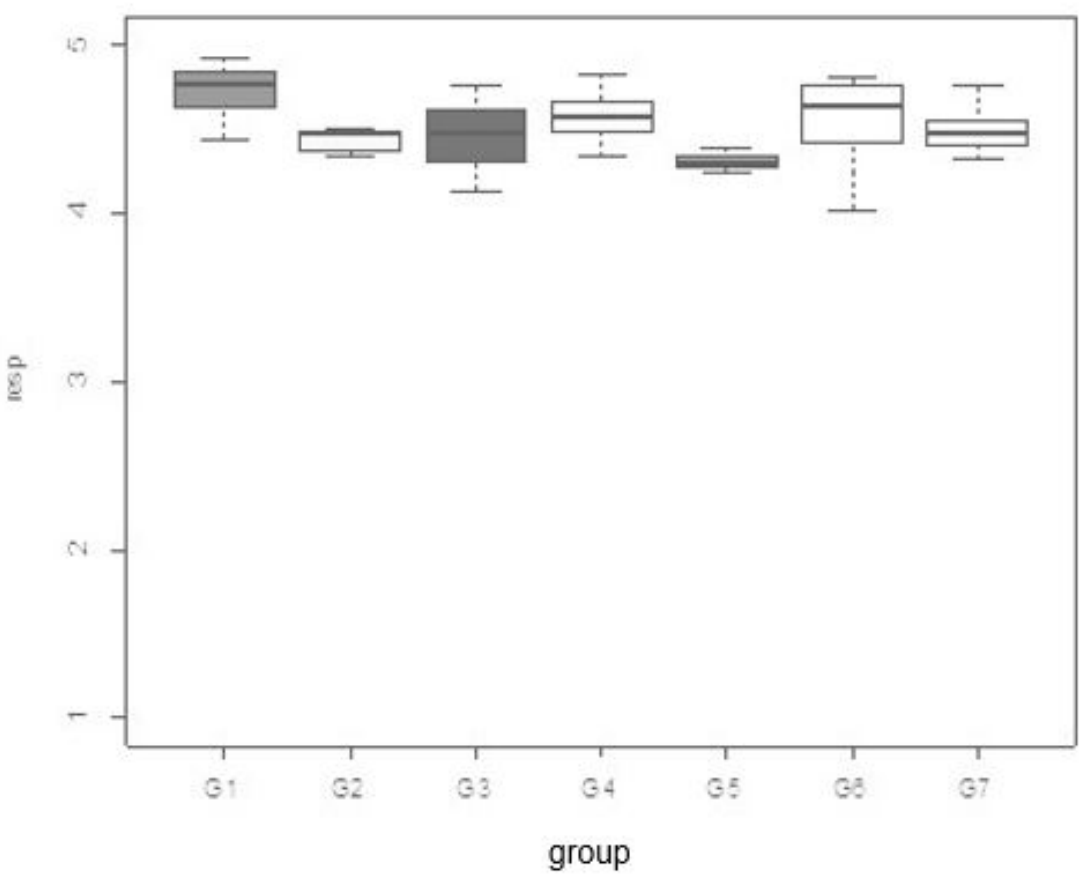

Subtitle:

G1: Alignment with military precepts

G2: Organizational

G3: Knowledge

G4: Interpersonal

G5: Communication

G6: Delivery (task results)

G7: Influence others

Figure 6 - Distribution of senior officers' responses.

Source: R Software (2018).

It is noticed that there was a low amplitude in the dispersion of the responses, all of which were grouped above 4 on a scale of 1 to 5 . Also noteworthy is the low dispersion around a high average value obtained in Group 1 - Alignment to military precepts.

Regarding the warrant officers, the answers were distributed as shown in Chart 5:

Chart 5 - Distribution of warrant officers' responses.

\begin{tabular}{|cccccc|}
\hline COMPETENCIES & \multicolumn{5}{c|}{ Number of responses } \\
\hline $\begin{array}{c}\text { ALIGNMENT WITH MILITARY } \\
\text { PRECEPTS: }\end{array}$ & 1 & 2 & 3 & 4 & 5 \\
\hline C1 & $0.14 \%$ & $0.00 \%$ & $2.20 \%$ & $23.93 \%$ & $73.73 \%$ \\
\hline C2 & $0.14 \%$ & $0.14 \%$ & $0.28 \%$ & $5.36 \%$ & $94.09 \%$ \\
\hline C3 & $0.28 \%$ & $0.00 \%$ & $1.79 \%$ & $17.33 \%$ & $80.61 \%$ \\
\hline C4 & $0.41 \%$ & $0.00 \%$ & $0.55 \%$ & $11.55 \%$ & $87.48 \%$ \\
\hline C5 & $0.14 \%$ & $0.00 \%$ & $1.24 \%$ & $18.43 \%$ & $80.19 \%$ \\
\hline C6 & $0.14 \%$ & $0.00 \%$ & $1.65 \%$ & $19.39 \%$ & $78.82 \%$ \\
\hline
\end{tabular}


Proposal for updating the Aeronautic enlisted men's evaluating performance instrument based on the perceptions of senior and warrant officers

Charts 5 - Continued...

\begin{tabular}{|c|c|c|c|c|c|}
\hline COMPETENCIES & \multicolumn{5}{|c|}{ Number of responses } \\
\hline \multirow{2}{*}{ ORGANIZATIONAL: } & \multicolumn{5}{|c|}{ Number of responses } \\
\hline & 1 & 2 & 3 & 4 & 5 \\
\hline C7 & $0.14 \%$ & $0.00 \%$ & $2.61 \%$ & $32.32 \%$ & $64.92 \%$ \\
\hline C8 & $0.28 \%$ & $0.28 \%$ & $4.13 \%$ & $39.61 \%$ & $55.71 \%$ \\
\hline C9 & $0.69 \%$ & $1.51 \%$ & $8.53 \%$ & $35.35 \%$ & $53.92 \%$ \\
\hline $\mathrm{C} 10$ & $0.00 \%$ & $0.55 \%$ & $2.89 \%$ & $27.65 \%$ & $68.91 \%$ \\
\hline C11 & $0.28 \%$ & $0.69 \%$ & $5.5 \%$ & $29.02 \%$ & $64.51 \%$ \\
\hline \multirow{2}{*}{ KNOWLEDGE: } & \multicolumn{5}{|c|}{ Number of responses } \\
\hline & 1 & 2 & 3 & 4 & 5 \\
\hline C12 & $0.14 \%$ & $0.83 \%$ & $3.71 \%$ & $25.45 \%$ & $69.88 \%$ \\
\hline C13 & $0.41 \%$ & $0.28 \%$ & $2.20 \%$ & $17.47 \%$ & $79.64 \%$ \\
\hline C14 & $0.55 \%$ & $1.10 \%$ & $5.64 \%$ & $35.49 \%$ & $57.22 \%$ \\
\hline \multirow{2}{*}{ INTERPERSONAL: } & \multicolumn{5}{|c|}{ Number of responses } \\
\hline & 1 & 2 & 3 & 4 & 5 \\
\hline C15 & $0.14 \%$ & $0.28 \%$ & $2.20 \%$ & $28.34 \%$ & $69.05 \%$ \\
\hline C16 & $0.00 \%$ & $0.28 \%$ & $0.96 \%$ & $18.84 \%$ & $79.92 \%$ \\
\hline C17 & $0.28 \%$ & $0.00 \%$ & $5.50 \%$ & $34.25 \%$ & $59.97 \%$ \\
\hline C18 & $0.14 \%$ & $0.00 \%$ & $3.44 \%$ & $31.50 \%$ & $64.92 \%$ \\
\hline C19 & $0.83 \%$ & $0.28 \%$ & $6.19 \%$ & $30.26 \%$ & $62.45 \%$ \\
\hline $\mathrm{C} 20$ & $0.14 \%$ & $0.00 \%$ & $0.28 \%$ & $6.46 \%$ & $93.12 \%$ \\
\hline \multirow{2}{*}{ COMUNNICATION: } & \multicolumn{5}{|c|}{ Number of responses } \\
\hline & 1 & 2 & 3 & 4 & 5 \\
\hline $\mathrm{C} 21$ & $0.28 \%$ & $0.00 \%$ & $2.89 \%$ & $32.19 \%$ & $64.65 \%$ \\
\hline $\mathrm{C} 22$ & $0.14 \%$ & $0.28 \%$ & $2.34 \%$ & $32.74 \%$ & $64.51 \%$ \\
\hline C23 & $0.00 \%$ & $0.14 \%$ & $3.71 \%$ & $35.9 \%$ & $60.25 \%$ \\
\hline \multirow{2}{*}{ DELIVERY (TASK RESULTS): } & \multicolumn{5}{|c|}{ Number of responses } \\
\hline & 1 & 2 & 3 & 4 & 5 \\
\hline C24 & $0.14 \%$ & $0.28 \%$ & $1.65 \%$ & $24.07 \%$ & $73.87 \%$ \\
\hline $\mathrm{C} 25$ & $0.14 \%$ & $0.55 \%$ & $3.16 \%$ & $35.90 \%$ & $60.25 \%$ \\
\hline C26 & $0.28 \%$ & $0.41 \%$ & $2.20 \%$ & $25.17 \%$ & $71.94 \%$ \\
\hline $\mathrm{C} 27$ & $0.14 \%$ & $0.14 \%$ & $2.75 \%$ & $33.98 \%$ & $63.00 \%$ \\
\hline $\mathrm{C} 28$ & $0.69 \%$ & $1.1 \%$ & $13.76 \%$ & $46.08 \%$ & $38.38 \%$ \\
\hline C29 & $0.28 \%$ & $0.14 \%$ & $2.48 \%$ & $18.71 \%$ & $78.40 \%$ \\
\hline C30 & $0.14 \%$ & $0.14 \%$ & $0.83 \%$ & $6.74 \%$ & $92.16 \%$ \\
\hline \multirow{2}{*}{ INFLUENCE OTHERS: } & \multicolumn{5}{|c|}{ Number of responses } \\
\hline & 1 & 2 & 3 & 4 & 5 \\
\hline C31 & $0.28 \%$ & $0.14 \%$ & $0.96 \%$ & $12.79 \%$ & $85.83 \%$ \\
\hline C32 & $0.28 \%$ & $0.00 \%$ & $1.24 \%$ & $18.16 \%$ & $80.33 \%$ \\
\hline C33 & $0.69 \%$ & $0.00 \%$ & $2.06 \%$ & $20.5 \%$ & $76.75 \%$ \\
\hline C34 & $0.28 \%$ & $0.14 \%$ & $1.51 \%$ & $26.55 \%$ & $71.53 \%$ \\
\hline C35 & $0.14 \%$ & $0.41 \%$ & $1.79 \%$ & $26.82 \%$ & $70.84 \%$ \\
\hline C36 & $0.14 \%$ & $0.28 \%$ & $0.96 \%$ & $18.98 \%$ & $79.64 \%$ \\
\hline C37 & $0.28 \%$ & $0.14 \%$ & $4.81 \%$ & $33.29 \%$ & $61.49 \%$ \\
\hline
\end{tabular}

Source: the author. 
Likewise, a boxplot graph was used to identify the range of distribution of the warrant officers' responses (Figure 7).

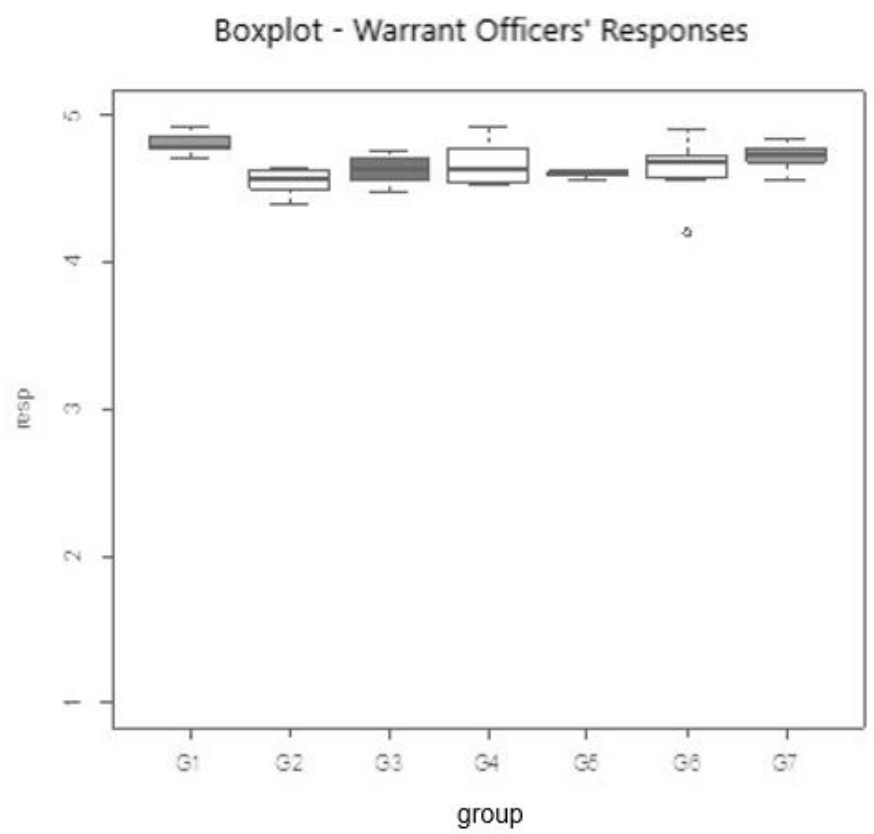

Subtitle:

G1: Alignment with military

precepts

G2: Organizational

G3: Knowledge

G4: Interpersonal

G5: Communication

G6: Delivery (task results)

G7: Influence others

Figure 7 - Distribution of warrant officers' responses.

Source: R Software (2018).

As in the officers answers, there was a low amplitude dispersion in the warrant officers' answers. They were also grouped above 4 in a scale of 1 to 5 . The Group 1 also obtained low dispersion around a high average.

After calculating the average $(\bar{X})$, the standard deviation and the CV for each competency, they were scaled using the latter value as reference. The result is summarized in Charts 6 .

Charts 6 - Results obtained after analysis by group of respondents.

\begin{tabular}{cccccccc}
\hline \multicolumn{3}{c}{ Senior officers } & \multicolumn{5}{c}{ Warrant officers } \\
\hline Competency & Average & Deviation & CV & Competency & Average & Deviation & CV \\
\hline C2 & 4.93 & 0.33 & $6.59 \%$ & C20 & 4.92 & 0.30 & $6.16 \%$ \\
C1 & 4.83 & 0.43 & $8.80 \%$ & C2 & 4.93 & 0.31 & $6.23 \%$ \\
C20 & 4.83 & 0.44 & $9.06 \%$ & C30 & 4.91 & 0.36 & $7.24 \%$ \\
C4 & 4.84 & 0.45 & $9.21 \%$ & C4 & 4.86 & 0.43 & $8.82 \%$ \\
C24 & 4.8 & 0.47 & $9.88 \%$ & C31 & 4.84 & 0.44 & $9.17 \%$ \\
\hline
\end{tabular}


Proposal for updating the Aeronautic enlisted men's evaluating performance instrument based on the perceptions of senior and warrant officers

\section{Charts 6 - Continued...}

\begin{tabular}{|c|c|c|c|c|c|c|c|}
\hline \multicolumn{4}{|c|}{ Senior officers } & \multicolumn{4}{|c|}{ Warrant officers } \\
\hline Competency & Average & Deviation & CV & Competency & Average & Deviation & CV \\
\hline C13 & 4.75 & 0.50 & $10.48 \%$ & C16 & 4.78 & 0.45 & $9.47 \%$ \\
\hline C30 & 4.8 & 0.50 & $10.51 \%$ & $\mathrm{C} 5$ & 4.79 & 0.46 & $9.58 \%$ \\
\hline C31 & 4.75 & 0.53 & $11.18 \%$ & C36 & 4.78 & 0.48 & $9.95 \%$ \\
\hline C29 & 4.72 & 0.54 & $11.45 \%$ & C32 & 4.78 & 0.48 & $9.99 \%$ \\
\hline C16 & 4.66 & 0.55 & $11.82 \%$ & $\mathrm{C} 6$ & 4.77 & 0.48 & $10.02 \%$ \\
\hline $\mathrm{C} 25$ & 4.63 & 0.56 & $12.05 \%$ & $\mathrm{C} 3$ & 4.78 & 0.49 & $10.27 \%$ \\
\hline $\mathrm{C} 3$ & 4.69 & 0.59 & $12.52 \%$ & $\mathrm{C} 1$ & 4.71 & 0.52 & $10.95 \%$ \\
\hline $\mathrm{C} 5$ & 4.62 & 0.58 & $12.61 \%$ & C24 & 4.71 & 0.52 & $11.05 \%$ \\
\hline C32 & 4.60 & 0.60 & $13.06 \%$ & C29 & 4.75 & 0.53 & $11.13 \%$ \\
\hline C15 & 4.59 & 0.62 & $13.51 \%$ & C34 & 4.69 & 0.53 & $11.41 \%$ \\
\hline $\mathrm{C7}$ & 4.50 & 0.62 & $13.80 \%$ & C13 & 4.76 & 0.54 & $11.41 \%$ \\
\hline C19 & 4.54 & 0.64 & $14.11 \%$ & C35 & 4.68 & 0.54 & $11.62 \%$ \\
\hline C8 & 4.49 & 0.64 & $14.20 \%$ & C15 & 4.66 & 0.55 & $11.80 \%$ \\
\hline C26 & 4.47 & 0.66 & $14.81 \%$ & C7 & 4.62 & 0.55 & $11.96 \%$ \\
\hline C10 & 4.48 & 0.68 & $15.17 \%$ & C33 & 4.73 & 0.57 & $12.03 \%$ \\
\hline C36 & 4.50 & 0.68 & $15.17 \%$ & $\mathrm{C} 26$ & 4.68 & 0.57 & $12.08 \%$ \\
\hline $\mathrm{C} 17$ & 4.48 & 0.68 & $15.21 \%$ & $\mathrm{C} 10$ & 4.65 & 0.56 & $12.15 \%$ \\
\hline $\mathrm{C} 12$ & 4.48 & 0.68 & $15.28 \%$ & $C 22$ & 4.61 & 0.56 & $12.22 \%$ \\
\hline C34 & 4.46 & 0.68 & $15.31 \%$ & $\mathrm{C} 27$ & 4.60 & 0.57 & $12.33 \%$ \\
\hline C6 & 4.44 & 0.68 & $15.35 \%$ & C18 & 4.61 & 0.57 & $12.34 \%$ \\
\hline $\mathrm{C} 23$ & 4.39 & 0.69 & $15.63 \%$ & $\mathrm{C} 21$ & 4.61 & 0.57 & $12.45 \%$ \\
\hline $\mathrm{C} 22$ & 4.30 & 0.67 & $15.64 \%$ & $\mathrm{C} 23$ & 4.56 & 0.57 & $12.57 \%$ \\
\hline $\mathrm{C} 27$ & 4.36 & 0.70 & $16.01 \%$ & C12 & 4.64 & 0.61 & $13.12 \%$ \\
\hline C35 & 4.47 & 0.72 & $16.14 \%$ & C25 & 4.56 & 0.60 & $13.17 \%$ \\
\hline C11 & 4.38 & 0.72 & $16.44 \%$ & C37 & 4.56 & 0.62 & $13.62 \%$ \\
\hline $\mathrm{C} 21$ & 4.25 & 0.72 & $17.01 \%$ & C8 & 4.50 & 0.62 & $13.74 \%$ \\
\hline C33 & 4.34 & 0.74 & $17.03 \%$ & C17 & 4.54 & 0.63 & $13.81 \%$ \\
\hline C9 & 4.34 & 0.75 & $17.34 \%$ & C11 & 4.57 & 0.66 & $14.36 \%$ \\
\hline C18 & 4.33 & 0.77 & $17.69 \%$ & C19 & 4.53 & 0.70 & $15.43 \%$ \\
\hline C37 & 4.32 & 0.77 & $17.77 \%$ & C14 & 4.48 & 0.70 & $15.71 \%$ \\
\hline C14 & 4.13 & 0.79 & $19.16 \%$ & C9 & 4.40 & 0.77 & $17.38 \%$ \\
\hline C28 & 4.02 & 0.82 & $20.41 \%$ & $\mathrm{C} 28$ & 4.20 & 0.77 & $18.22 \%$ \\
\hline
\end{tabular}

Source: the author.

The competencies indicated in those charts correspond to that obtained a CV value of less than 15\%, which represents, according to Martins (2005), a low dispersion.

It is noticed that the number of competencies seen as necessary for enlisted perform their functions diverged between respondent groups, ranking 19 for senior officers and in 33 to warrant officers. When analyzing the responses in general, we achieve the result contained in Chart 7.

Chart 7 - General Result.

\begin{tabular}{cccc}
\hline \multicolumn{3}{c}{ General Result } & \\
\hline Competency & Average & Deviation & CV \\
\hline C2 & 4.93 & 0.32 & $6.41 \%$ \\
C20 & 4.88 & 0.38 & $7.73 \%$ \\
\hline
\end{tabular}


Charts 7 - Continued...

\begin{tabular}{|c|c|c|c|}
\hline \multicolumn{4}{|c|}{ General Result } \\
\hline Competency & Average & Deviation & CV \\
\hline C30 & 4.86 & 0.44 & $9.00 \%$ \\
\hline $\mathrm{C} 4$ & 4.85 & 0.44 & $9.00 \%$ \\
\hline $\mathrm{C} 1$ & 4.77 & 0.48 & $10.02 \%$ \\
\hline C31 & 4.80 & 0.49 & $10.21 \%$ \\
\hline $\mathrm{C} 24$ & 4.75 & 0.50 & $10.53 \%$ \\
\hline C16 & 4.72 & 0.51 & $10.72 \%$ \\
\hline C13 & 4.75 & 0.52 & $10.97 \%$ \\
\hline C5 & 4.71 & 0.53 & $11.23 \%$ \\
\hline $\mathrm{C} 29$ & 4.74 & 0.53 & $11.29 \%$ \\
\hline $\mathrm{C} 3$ & 4.74 & 0.54 & $11.43 \%$ \\
\hline C32 & 4.69 & 0.55 & $11.68 \%$ \\
\hline C15 & 4.62 & 0.59 & $12.66 \%$ \\
\hline $\mathrm{C} 25$ & 4.59 & 0.58 & $12.66 \%$ \\
\hline $\mathrm{C7}$ & 4.56 & 0.59 & $12.92 \%$ \\
\hline C36 & 4.64 & 0.60 & $12.95 \%$ \\
\hline $\mathrm{C} 6$ & 4.61 & 0.61 & $13.17 \%$ \\
\hline C34 & 4.58 & 0.62 & $13.56 \%$ \\
\hline $\mathrm{C} 26$ & 4.58 & 0.62 & $13.60 \%$ \\
\hline C10 & 4.57 & 0.63 & $13.75 \%$ \\
\hline $\mathrm{C} 8$ & 4.50 & 0.63 & $13.96 \%$ \\
\hline C35 & 4.58 & 0.64 & $14.07 \%$ \\
\hline $\mathrm{C} 23$ & 4.48 & 0.64 & $14.20 \%$ \\
\hline C12 & 4.56 & 0.65 & $14.28 \%$ \\
\hline $\mathrm{C} 22$ & 4.46 & 0.64 & $14.29 \%$ \\
\hline $\mathrm{C} 27$ & 4.48 & 0.64 & $14.37 \%$ \\
\hline C17 & 4.51 & 0.65 & $14.50 \%$ \\
\hline C19 & 4.54 & 0.67 & $14.80 \%$ \\
\hline C33 & 4.54 & 0.68 & $15.06 \%$ \\
\hline $\mathrm{C} 21$ & 4.43 & 0.67 & $15.21 \%$ \\
\hline C18 & 4.48 & 0.69 & $15.32 \%$ \\
\hline C11 & 4.48 & 0.69 & $15.50 \%$ \\
\hline C37 & 4.44 & 0.71 & $15.87 \%$ \\
\hline C9 & 4.37 & 0.76 & $17.37 \%$ \\
\hline C14 & 4.31 & 0.77 & $17.79 \%$ \\
\hline C28 & 4.11 & 0.80 & $19.39 \%$ \\
\hline
\end{tabular}

Source: the author.

Chart 7 illustrates that using the parameters that guided this study, the number of competencies understood both by senior and warrant officers as necessary to enlisted in the performance of their duties was 29. 


\section{Proposal to update the existing evaluation tool}

Due to the data analysis presented, the competencies presented in Chart 8 were established:

Chart 8 - Competencies for updating the Enlisted Men Evaluation System.

\begin{tabular}{|c|c|c|}
\hline GROUP & COMPETENCIES & $\begin{array}{c}\text { COEFICIENT } \\
\text { OF } \\
\text { VARIATION }\end{array}$ \\
\hline \multirow{6}{*}{$\begin{array}{l}\text { ALIGNMENT WITH } \\
\text { MILITARY PRECEPTS }\end{array}$} & Advising with loyalty and honesty of purpose. & $6.41 \%$ \\
\hline & Comply with and demand compliance with the Institution's rules. & $9.00 \%$ \\
\hline & Accept superior decisions. & $10.02 \%$ \\
\hline & Be punctual. & $11.23 \%$ \\
\hline & $\begin{array}{l}\text { Behave in accordance with military principles and values and with } \\
\text { organizational culture (rites, rituals, ceremonies and social events). }\end{array}$ & $11.43 \%$ \\
\hline & $\begin{array}{l}\text { Maintain the personal presentation and their uniforms in accordance with } \\
\text { the standards established by the Institution. }\end{array}$ & $13.17 \%$ \\
\hline \multirow{3}{*}{ ORGANIZATIONAL } & $\begin{array}{l}\text { Adopt techniques and methods of using resources that optimize the } \\
\text { meeting of organizational needs. }\end{array}$ & $12.92 \%$ \\
\hline & $\begin{array}{l}\text { Establish procedures to ensure control and quality in the delivery of the } \\
\text { task. }\end{array}$ & $13.75 \%$ \\
\hline & Be flexible when facing new ideas and situations, adapting to changes. & $13.96 \%$ \\
\hline \multirow{2}{*}{ KNOWLEDGE } & $\begin{array}{l}\text { Retain and apply the technical-professional knowledge required for your } \\
\text { function. }\end{array}$ & $10.97 \%$ \\
\hline & $\begin{array}{l}\text { Search for knowledge that will improve the performance of your role (self- } \\
\text { development). }\end{array}$ & $14.28 \%$ \\
\hline \multirow{5}{*}{ INTERPERSONAL } & Treat your superiors, peers and subordinates with respect and education. & $7.73 \%$ \\
\hline & $\begin{array}{l}\text { Cooperate in teamwork in order to optimize the achievement of the } \\
\text { proposed objectives. }\end{array}$ & $10.72 \%$ \\
\hline & Maintain self-control in situations of pressure and stress. & $12.66 \%$ \\
\hline & Receive mature criticism. & $14.50 \%$ \\
\hline & State your opinions frankly and appropriately. & $14.80 \%$ \\
\hline \multirow{2}{*}{ COMUNNICATION } & Listen carefully and react constructively to the other's point of view. & $14.20 \%$ \\
\hline & Express yourself orally in a clear, logical and concise manner. & $14.29 \%$ \\
\hline \multirow{6}{*}{$\begin{array}{l}\text { DELIVERY (TASK } \\
\text { RESULTS) }\end{array}$} & $\begin{array}{l}\text { Take responsibility for your own mistakes, not blaming other team } \\
\text { members. }\end{array}$ & $9.00 \%$ \\
\hline & Comply with the established deadlines. & $10.53 \%$ \\
\hline & $\begin{array}{l}\text { Keep your boss informed about progress and problems in carrying out } \\
\text { tasks, avoiding surprises. }\end{array}$ & $11.29 \%$ \\
\hline & Maintain commitment to goals in the face of obstacles and frustrations. & $12.66 \%$ \\
\hline & Plan, organize and prioritize actions to achieve the objectives. & $13.60 \%$ \\
\hline & $\begin{array}{l}\text { Judge with discretion and impartiality the aspects involved in carrying out } \\
\text { the task. }\end{array}$ & $14.37 \%$ \\
\hline \multirow{5}{*}{ INFLUENCE OTHERS } & Set an example of behavior and conduct for your peers and subordinates. & $10.21 \%$ \\
\hline & Stimulate body spirit and teamwork. & $11.68 \%$ \\
\hline & Ensure the well-being of your peers in the workplace. & $12.95 \%$ \\
\hline & $\begin{array}{l}\text { Mobilize and guide team members with a view to achieving the } \\
\text { established goals. }\end{array}$ & $13.56 \%$ \\
\hline & Provide feedback to subordinates regarding the results obtained. & $14.07 \%$ \\
\hline
\end{tabular}

Source: The author.

The 29 competencies that make up the list above represent a portrait of what is expected of Air Force enlisted, resulting from the existing reality and based on the perception of senior and warrant officers. Such competencies outline a much more complete behavioral picture than the current one, consisting of 15 competencies, and may be the basis to come to update the instrument used in the performance evaluation of enlisted in order to adapt it to the reality of the various organizations. 
Not to mention that the only group of competencies that got acceptance in general was the Thread the Alignment with military precepts, which suggests the value and influence of values and organizational culture.

Most respondents ( $89 \%$ of senior officers and $77.6 \%$ of warrant officers) understood that the competencies presented in the questionnaire proved to be satisfactory for the scope of the survey. However, it is interesting to record some of the main competencies presented, understood as relevant, which were not on the list and which are common points in the considerations of both senior and warrant officers:

- Exercise leadership;

- maintain physical health; and

- enable themselves in foreign languages (English and Spanish).

In regards to the exercise of leadership, for this research was used the concept to influence others, since it is not expected to enlisted the direct exercise of leadership due to the hierarchical level and career peculiarities, but the influence exerted is rather a factor to be considered.

But it is interesting to highlight that a committed leadership, together with the engagement of subordinates, are essential factors to guarantee the competitiveness of an organization (Ferreira et al., 2019), validating the importance of maintaining competencies aligned with this concept.

As for the question of considering the registration of the enlisted tasks important and the respective evaluation of the established goals achievement, the majority of respondents considered this registration important $(89.5 \%$ of the senior officers and $91.5 \%$ of warrant officers). This record allows and tracks performance in the specific tasks assigned to each military.

\section{CONCLUSIONS AND SUGGESTIONS FOR FUTURE STUDIES}

Due to the restructuring that the Air Force has been going through, started in 2016, the work of the Secretaries of the Promotions Commissions of Officers and Enlisted Men was unified. As a result of this unification, it was identified the need to raise which competencies were necessary for the Aeronautic enlisted to perform their functions and that could be considered for updating the existing performance evaluation instrument.

A bibliographic and documentary survey was carried out in order to identify which existing competencies, understood as appropriate for enlisted to perform their duties, could compose a questionnaire.

From this survey, a questionnaire was prepared and sent to senior and warrant officers, so that they could identify, from their perspective, which competencies, among those listed, were understood as necessary to the proposed objective.

With the data collected, the characteristics of each group of respondents were represented, as well as the distribution of responses received. Later, were raised information such as average, standard deviation and coefficient of variation of Pearson, which permitted to identify among the listed competencies, and based on established criteria, those were considered necessary, either by senior and by the warrant officers, to Air Force enlisted in the performance of their duties.

Most respondents considered the competencies on the list to be satisfactory for the purposes of the present work, as well as considering the registration of the tasks of the enlisted and the respective evaluation of the established goals achievement.

After analysis and tabulation of the data, the importance of military values, ethics and military duty, and organizational culture in the identification of the necessary competencies for military personnel was evidenced, since the only group that had none of the competencies excluded was the entitled "Alignment with military precepts".

As form of practical application of the results obtained in this study, it is expected that the identified competencies can contribute for future improvements to the evaluation system 
of Air Force enlisted performance, since such competencies were understood, both by senior as well as warrant officers, as essential for enlisted in the exercise of their functions.

As suggestions for future research, we highlight the possibility of carrying out studies to improve the evaluation systems of both officers and enlisted, as well as the identification of competencies for specific positions and functions in the field of Aeronautic.

\section{REFERÊNCIAS}

Almeida, C.A. (2013), Concepção e desenvolvimento de um protótipo de software genérico para avaliar a qualidade em serviços utilizando o método SERVQUAL, Dissertação de Mestrado em Engenharia na Universidade Federal do Paraná, Curitiba.

Arbache, A.P. and Dutra, D.A. (Org.) (2018), Recursos humanos: transformando pela gestão, FGV Editora, Rio de Janeiro.

Boyatzis, R.E. (1982), The competent manager: a model for effective performance, John Wiley \& Sons, New York.

Brasil. Comando da Aeronáutica. Portaria COMGEP n² 2515/DLE, de 25 de setembro de 2013. Aprova a reedição da Instrução do Comando da Aeronáutica que dispõe sobre a Avaliação de Desempenho dos Graduados do Comando da Aeronáutica (ICA 39-17). Boletim do Comando da Aeronáutica, Rio de Janeiro, n. 195, 09 out. 2013.

Brasil. Comando da Aeronáutica. Portaria CPO n³/SAP, de 26 de outubro de 2015. Aprova a reedição da Instrução do Comando da Aeronáutica que dispõe sobre a Avaliação de Desempenho de Oficiais da Aeronáutica (ICA 36-4). Boletim do Comando da Aeronáutica, Rio de Janeiro, n. 202, 04 nov. 2015.

Brasil. Comando da Aeronáutica. Portaria EMAER n 50/7SC, de 11 de outubro de 2016. Aprova a edição da Diretriz que dispõe sobre a unificação das atividades da Secretaria da Comissão de Promoções de Oficiais e da Secretaria da Comissão de Promoções de Graduados (DCA 11-60). Boletim do Comando da Aeronáutica, Rio de Janeiro, n. 177, 17 out. 2016.

Brasil. Comando da Aeronáutica. Portaria DIRAP n 791-T/SAPSM, de 06 de fevereiro de 2018. Aprova o Aviso de Convocação para a Seleção de Profissionais de Nível Médio Voluntários à Prestação do Serviço Militar Temporário, para o ano de 2018 (AC/QSCON 1/2018). Diário Oficial da União, Brasília, n. 27, Seção I, 07 fev. 2018.

Brasil. Comando da Aeronáutica. Portaria n 165/GC3, de 24 de janeiro de 2017. Aprova a reedição da Instrução que dispõe sobre a Prestação de Tarefa por Tempo Certo no âmbito do Comando da Aeronáutica (ICA 35-13). Boletim do Comando da Aeronáutica, Rio de Janeiro, n. 15, 26 jan. 2017.

Brasil. Comando da Aeronáutica. Portaria n551/GC3, de 13 de maio de 2016. Aprova a edição da Diretriz que dispõe sobre a Reestruturação da Força Aérea Brasileira (DCA 11-53). Boletim do Comando da Aeronáutica, Rio de Janeiro, n. 082, 17 maio. 2016b.

Brasil. Decreto $n^{\circ} 3.690$, de 19 de dezembro de 2000. Aprova o Regulamento do Corpo do Pessoal Graduado da Aeronáutica, available at: http://www.planalto.gov.br/ccivil_03/decreto/D3690.htm (acessed 09 February, 2018).

Brasil. Decreto $\mathrm{n}^{\circ}$ 88.455, de 4 de julho de 1983. Regulamenta a designação de militar da reserva remunerada das Forças Armadas para o serviço ativo prevista no Estatuto dos Militares, available at: http://www.planalto.gov.br/ccivil_03/decreto/1980-1989/D88455.htm (acessed 05 October 2018).

Brasil. Lei $n^{\circ}$ 6.880, de 09 de dezembro de 1980. Dispõe sobre o Estatuto dos Militares, available at: http://www.planalto.gov.br/ccivil_03/Leis/L6880.htm (acessed 09 February 2018).

Carbone, P.P. et al. (2016), Gestão por competências, FGV Editora, Rio de Janeiro.

Cripe, E.J. and Mansfield, R. (2003), Profissionais disputados: as 31 competências de quem agrega valor nas empresas, Campus, Rio de Janeiro, Tradução: Pepe, E.

Chiavenato, I. (2014), Gestão de Pessoas: o novo papel dos recursos humanos nas organizações, 4. ed., Prentice Hall, São Paulo.

Dutra, J.S. (2011), Competências: conceitos e instrumentos para a gestão de pessoas na empresa moderna, 1. ed. 9. reimpr. Atlas, São Paulo.

Dutra, J.S. (2014), Gestão de pessoas: modelo, processos, tendências e perspectivas, 1. ed. 13. reimpr. Atlas, São Paulo. 
NATO (2020), English Styleguide, available at: https://www.nato.int/clearwriting/clearwriting_files/docs /clearwriting_styleguide.pdf (acessed 15 May 2020).

Ferreira, S., Neto, J. and Batista, H. (2019), "Critical success factors on project and process management in competitive strategy implementation", Brazilian Journal of Operations \& Production Management, Vol. 16, No. 4, pp. 605-16. http://dx.doi.org/10.14488/BJOPM.2019.v16.n4.a6.

Fleury, A. and Fleury, M.T.L. (2008) Estratégias empresariais e formação de competências: um quebra-cabeça caleidoscópico da indústria brasileira, 3. ed. 4. reimpr. Atlas, São Paulo.

Gil, A.C. (2010), Como elaborar projetos de pesquisa, 5. ed. Atlas, São Paulo.

LeBortef, G. (1995), De la compétence, Editions d'Organisations, France.

Ludolf, N., Silva, M., Gomes, C.F.S. et al. (2017), "The organizational culture and values alignment management importance for successful business", Brazilian Journal of Operations \& Production Management, Vol. 14, No. 2, pp. 272-80. http://dx.doi.org/10.14488/BJOPM.2017.v14.n2.a15.

Mariano, F. and Meneses, A. (2014), Estatística básica e inferencial para concursos, 1. ed. Elsevier, Rio de Janeiro.

Marôco, J. (2014), Análise estatística com o SPSS Statistics, 6. ed. ReportNumber, Pêro Pinheiro.

Martins, G.A. (2005), Estatística geral e aplicada, 3. ed. Atlas, São Paulo.

Mussak, E. (2010), "A nova competência", Revista Você S/A, 21 fevereiro, available at: https://www.eugeniomussak.com.br/2010/02/21/a-nova-competencia/ (acessed 12 June 2018).

R Software (2018). R: A language and environment for statistical computing, Vienna, Austria, R Foundation for Statistical Computing, available at: https://www.R-project.org/ (acessed 25 October 2018).

SISPROM (2018), "Officers Promotions System".

Spencer, L.M. and Spencer, S. (1993), Competence at work, John Wiley \& Sons, New York.

Vergara, S.C. (2012), Métodos de coleta de dados no campo, 2. ed. Atlas, São Paulo.

Zarifian, P. (1996), A gestão da e pela competência, Centro Internacional para Educação, Trabalho e Transferência de Tecnologia, Rio de Janeiro.

Zarifian, P. (2001), Objetivo competência: por uma nova lógica, Tradução: Trylinski, MHCV. Atlas, São Paulo.

Author contributions: Guilherme dos Santos Araújo: data collection, writing, managing the project. Fernando Oliveira de Araujo: review, managing the project. 